\title{
HUKUM PERNIKAHAN DI KESULTANAN MELAKA ABAD KE-15 DAN KE-16 M.
}

\section{Ayang Utriza Yakin}

Indonesian Sharia Watch

Peneliti Pusat Pengkajian Islam dan Masyarakat UIN Jakarta

Email: ayang.utriza@uinjkt.ac.id

\begin{abstract}
This article examines legal aspects of Marriage law in the Sultanate of Malaka in the $15^{\text {th }}$ and $16^{\text {th }}$ centuries. It focuses on some legal aspects of Undang-undang Melaka (a text of laws of Melaka) represented by Liaw Yock. Fang, regarding the issues of marriage such as wali (marriage guardian), ijäb-qabül (consent of both parties), witness(es), taläq (repudiation), faskh (broken marriage contract), interfaith marriage and marrying slave. This study aims to know the source of the marriage laws of UndangUndang Melaka (UUM). It shows that UUM was a collection of common law in Melaka and consisted of Islamic law. One aspect of Islamic laws was marriage law. In UUM, the legal aspect was based on fiqh of several schools (madhbab), particularly the al-Shäfic school derived from atIqnä' written by al-Sharbini. This finding also refuses the previous research finding stating that it was derived from al-Taqrïby $A b \bar{u} S$ bujā'
\end{abstract}

Key words: Melaka, Sultanate, Undang-Undang Melaka, marriage, marriage Guardian, ijäb-qabül, and țaläq.

DO I: http://dx.doi.org/10.20414/ujis.v19i1.1248

\section{Pendahuluan}

KAJIAN atas sejarah dan arkeologi terkait dengan Kesultanan Melaka sudah banyak dibahas para sarjana. Akan tetapi, kajian terhadap sejarah hukum Kesultanan Melaka boleh dikatakan hanya sedikit sekali atau bahkan jarang. Kajian teks hukum atas Undang-Undang Melaka dapat ditegaskan belum ada yang mengkajinya secara utuh dan mendalam. ${ }^{1}$ Oleh karena itu,

${ }^{1}$ Lihat misalnya M. B. Hooker, Islamic Law in South South-East Asia (Singapore: Oxford University Press, 1984) dan M.B. Hooker, "A Note on

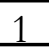


sangatlah penting untuk membahasnya secara mendalam untuk mengetahui sumber hukum di dalam UUM tersebut.

Untuk menjawabnya, maka struktur artikel adalah sebagai berikut. Pertama, artikel ini akan memberikan penjelasan tentang letak geografis, sejarah awal Melaka, dan proses islamisasi Melaka. Kedua, artikel ini akan membahas para sultan Melaka dan pergantian kekuasaannya serta keadaan politik internasional dan ekonomi dan keagamaan di Melaka. Ketiga, artikel ini akan membahas isu utama dalam artikel ini, yaitu kajian hukum atas teks UUM. Bahan utama artikel ini adalah sumber utama pada masa tersebut, yaitu Undang-Undang Melaka (UUM) dan ditambah dengan sumber-sumber utama lainnya serta historiografi tentang Kesultanan Melaka.

\section{Letak Geografis}

Melaka terletak di pesisir Barat Semenanjung Melayu. Sejak abad ke-5 M., penduduk Semenanjung Melayu adalah pemeluk agama Hindu dan Budha. Hipotesis tersebut berdasarkan jejak arkeologis yang berasal, bagi agama Hindu dan Budha, dari masa abad ke-5 hingga ke-8 M. Pengaruh agama Budha meningkat dan agama tersebut berkembang saat Semenanjung Melayu berada di bawah kekuasaan kerajaan Budha Sriwijaya. Dari abad ke-10 hingga ke-13 M., Semenanjung mengalami perkembangan yang pesat berkat perdagangan. Pada saat itulah, para pedagang berdatangan dari Timur-Tengah, India, Jawa, Kamboja, Tiongkok, dan Burma. ${ }^{2}$ Pada abad ke-14 M., kerajaan agraris

the Malayan Legal Digests," Journal of The Malayan Branch Royal Asiatic Society XLI, no. I, (July 1968): 157-170, yang memberikan gambaran umum tentang hukum Islam di Asia Tenggara di mana ia hanya membahas sepintas tentang UUM. Hooker tidak membahas UUM secara mendalam, hanya sepintas. Lihat juga buku Jelani Harun, Undang-Undang Kesultanan Melayu dalam Perbandingan (Pulau Pinang: Universiti Sains Malaysia, 2008) yang membahas sebagian besar undang-undang di Dunia Melayu, antara lain UUM, tetapi sayang, ia tidak masuk ke dalam persoalan hukum Islam di dalam UUM secara rinci dan mendalam.

${ }^{2}$ Untuk sejarah Semenanjung Melayu sebelum pendirian kesultanan Melaka, lihat Michael Jacq-HergorC, The Malay Peninsula Crossroads Of The Maritime Silk Road (100 BC-1300 AD), penerjemah Victoria Hobson (Leiden. Boston. Köln: Brill, 2002), lihat secara khusus bab V, 107-134, bab VI, 143- 
Majapahit menguasai seluruh Semenanjung Melayu. ${ }^{3}$ Sepanjang kekuasaan Majapahit, kekuasaan baru muncul di Singapura yang dibangun oleh Prameswara, seorang pendatang dari Palembang.

\section{Pendirian Melaka}

Saat tinggal di Melaka pada 1511-1512, Alfonso Albuquerque menceritakan bahwa Prameswara (Parimicura) adalah seorang raja Hindu dari Palembang yang telah menikahi Parimicuri, ${ }^{4}$ puteri raja Batara Tumapel dari Jawa. Pernikahan tersebut terlaksana, karena alasan politik untuk memperkuat hubungan antara kedua raja itu. Prameswara telah berjanji akan membayar upeti kepada bapak mertuanya, akan tetapi ia tidak menepati janjinya. Batara Tumapel menyerangnya sebagai balasan. Mungkin karena takut, Prameswara melarikan diri bersama dengan para isterinya, anak-anaknya, budaknya, dan kasimnya. Ia tiba di Tumasik yang kemudian menjadi Singapura. ${ }^{5}$

Tome Pirès, berada di Melaka dari 1511 sampai 1515, mempertegas bahwa Prameswara, anak dari "Sam Agi Palimbao", yang berarti raja Palembang, , telah menikahi Prameswari, sepupu perempuan dari raja Jawa Batara Tumapel. Saat dia merasa sudah kuat, ia memberontak terhadap raja Jawa.

158, bab XII, 339-386, bab XIII, 391-441. Rolland Braddel, the Study of Ancient Times in the Malay Peninsula and Straits of Malacca (Kuala Lumpur: MBRAS, 1989). Ini buku yang sangat bagus untuk mengerti sejarah Semenanjung Melayu hingga jatuhnya Sriwijaya. R.O. Winstedt, "A History of Malaya," Journal of the Malayan Branch Royal Asiatic Society XIII, no. I (1935), lihat secara khusus bab I, 1-17 dan bab II, 18-36.

3Theodore G. TH. Pigeaud, Java in the 14th Century. A Study in Cultural History. The Nagara-Kertagama by Rakani Prapanca of Majapahit, 1365 A.D., jilid V, The Hague: M. Nijhoff, 1960-1963, jilid I, 11-12, jilid III, 17, jilid IV, 3233.

${ }^{4}$ Menurut Ferrand, ada ragam nama tersebut: prameswari, permaiswri, paramicuri dan parameswari, lihat G. Ferrand, Malaka: Le Malayu et Malayur (Paris: Impimerie Nationale, 1918), 28 dan 414.

${ }^{5}$ Afonso Albuquerque, The Commentaries of the Great Afonso Dalboquerque, jilid IV, jilid III, penerjemah Walter De Gray Birch (London: The Hakluyt Society, 1774), 72-73.

${ }^{6}$ Menurut Claude Guillot, Sam Agi Palimbao adalah bentuk Portugis yang berasal dari bahasa Melayu Sang Aji Palembang. Wawancara dengan Claude Guillot pada Senin 7 Februari 2005. 
Lalu, raja Jawa itu menyerangnya dan Prameswara melarikan diri ke Singapura bersama seluruh keluarganya. ${ }^{7}$

Menurut Sulalat al-Salatin (dikenal: Sejarah Melayu), Prameswara berkuasa selama tiga tahun di Singapura. Saudara sulung Temenggung, yaitu raja Patani, yang menganggap Singapura seperti salah satu daerah jajahannya, menyerang Prameswara untuk membalas kematian saudara kandungnya. Akan tetapi, Prameswara dan semua orang-orangnya sudah melarikan diri ke daerah pedalaman sepanjang sungai Muar, ${ }^{8}$ dan berdiam sebentar di sana. ${ }^{9}$

Dengan undangan penduduk Bintan, Prameswara pergi ke pulau mereka di mana, menurut Albuquerque, ia mendirikan Melaka. ${ }^{10}$ Menurut Pirès, Prameswara tinggal sejenak di Bintan, kemudian ia pergi ke Sungai Bertam di mana ia mendirikan kota Melaka. ${ }^{11}$ Berbeda dengan dua sumber Portugis tersebut, Sulalat al-Salatin menunjukkan bahwa dari Muar, Prameswara berangkat ke Kota Buruk, lalu ke Setang Ujung (Sungai Ujung ?) sebelum, pada akhirnya, ia tinggal di Sungai Bertam di mana ia membangun kota Melaka. ${ }^{12}$

Menurut Sulalat al-Salatin, Melaka adalah nama sebuah pohon di bawah mana Prameswara berteduh. ${ }^{13}$ Tetapi, menurut Albuquerque, Melaka berarti "pertemuan", karena banyak orang datang ke tempat itu dari berbagai penjuru. ${ }^{14}$ Prameswara berkuasa selama 23 tahun, yaitu 3 tahun di Singapura dan 20 tahun di Melaka. ${ }^{15}$ Menurut kajian Wang Gungwu, Prameswara ${ }^{16}$

7'Tomes Pirés, The Suma Oriental, An Account Of The East From The Red Sea To Japan, Written In Malacca And India In 1512-1515, jilid I, penyunting Armando Cortesao (New Delhi: Asian educational services, 1990), 230-32.

8Buyong Bin Adil, Sejarab Melaka Dalam Zaman Kerajaan Melayu (Kuala Lumpur: Dewan Bahasa dan Pustaka, 1973), 3 dan 7.

9 Tun Seri Lanang, Sulalat al-Salatin ya'ni Pertuturan Segala Raja-raja (Sejarah Melayu), penyunting Muhammad Haji Salleh (Kuala Lumpur: Dewan Bahasa dan Pustaka, 1997), 49. Albuquerque, The Commentaries of the Great..., 74-75, Pirès, The Suma Oriental..., 231-232.

${ }_{10}$ Albuquerque, The Commentaries of the Great ..., 75-76.

11Pirès, The Suma Oriental..., 231-2.

12Lanang, Sulalat al-Salatin..., 49.

13Ibid.

${ }^{14}$ Albuquerque, The Commentaries of the Great ..., 76.

${ }^{15}$ Ibid. 
adalah benar raja pertama Melaka dari tahun 1390 sampai $1413 / 1414 .{ }^{17}$

\section{Islam dan Para Sultan Melaka}

Setelah Prameswara meninggal, Megat Iskandar Shah, putranya, menjadi raja kedua Melaka. ${ }^{18}$ Di dalam Sulalat alSalatin, ia dinamakanRaja Kecil Besar atau Sultan Makota atau Sultan Megat. ${ }^{19}$ Selama kekuasaannya, menurut Pirès, Melaka sedikit demi sedikit berubah menjadi pelabuhan besar yang kedatangan banyak pedagang Muslim. ${ }^{20}$ «Xaquendarxa ${ }^{21}{ }$, demikian sumber-sumber Portugis menamakannya, memberikan para pedagang Muslim itu izin untuk mendirikan rumah dan masjid. Raja ini (1414-1423/24)22 mengambil keuntungan dari kehadiran para pedagang muslim yang menjadi kesayangannya.

Albuquerque, sumber Portugis lainnya, mempertegas tesis pindah agama Iskandar Shah melalui pernikahannya dengan puteri Sultan Pasai. ${ }^{23}$ Versi Albuquerque dan Pirès diperkuat oleh satu sumber Tiongkok yang melaporkan bahwa raja, yang memberikan upeti kepada kekaisaran Tiongkok, bernama Muhammad Iskandar Shah. ${ }^{24}$ Nama rajanya saja, Muhammad, sudah dapat membuat kita menduga bahwa ia adalah seorang

${ }^{16}$ Gelarnya Iskandar Shah, menurut Sulalat al-Salatin.

${ }^{17}$ Wang Gungwu, "The First Three Rulers of Malacca," Journal of the Malayan Branch Royal Asiatic Society XLI, no. I (July 1968): 11-22.

${ }^{18}$ Ibid.

${ }^{19 L a n a n g, ~ S u l a l a t ~ a l-S a l a t i n . . ., ~} 49$.

20Pirès, The Suma Oriental..., 241-242.

${ }^{21}$ Menurut Claude Guillot "Xaquendarxa" adalah bentuk Portugis dari kata Melayu Iskandar Shah. «X" adalah huruf «SH» dalam bahasa Portugis kuna. Jadi, dibaca Shaqendarsha yang sangat dekat dengan bentuk Melayu Iskandar Shah. Wawancara dengan Claude Guillot pada Senin 7 Februari 2005.

22Gungwu, "The First Three ...", 13.

${ }^{23}$ Albuquerque, The Commentaries of the Great ..., 77.

${ }^{24 R . J . ~ W i l k i n s o n, ~ " T h e ~ M a l a c c a ~ S u l t a n a t e . " ~ J o u r n a l ~ o f ~ t h e ~ M a l a y a n ~ B r a n c h ~}$ Royal Asiatic Society XIII, no. 2 (1935): 22-67 dan 27-28. Kenyataan bahwa nama Iskandar Shah adalah nama seorang muslim berdasarkan misi Tiongkok yang dipimpin oleh Cheng Ho. 
muslim ${ }^{25}$. Kepindahan agama Iskandar Shah memeluk agama Islam terjadi pada saat ia berusia 72 tahun. ${ }^{26}$ Pindah agama Islam dengan cara pernikahan adalah kebiasaan yang terjadi pada masa itu $^{27}$.

Sebaliknya, Godinho De Eredia (1610/1613) menunjukkan hal yang lebih radikal lagi dengan menganggap bahwa raja pertama Melaka sudah menjadi Muslim sejak 1411 dan karenanya seluruh Melaka sudah diislamkan. ${ }^{28}$ Islam menjadi agama resmi di Melaka pada masa Prameswara antara 1377 (tahun pendiri Melaka) dan 1409. Menurut C.O. Blagden, berdasarkan catatan Ma Huan, menjelaskan bahwa raja dan rakyatnya mengikuti aturan agama Islam dengan taat. ${ }^{29}$

Sulalat al-Salatin mengajukan satu pandangan yang amat berbeda: Raja Tengah, ${ }^{30}$ anak raja Iskandar Shah, masuk agama Islam dengan jalan di luar kebiasaan atau supranatural, yaitu melalui mimpi. Dalam mimpinya, Raja Tengah bertemu dengan Nabi Muhammad yang memerintahkannya mengucapkan dua kalimat syahadat dan Nabi memberikannya nama Muhammad. ${ }^{31}$ Raja Tengah belajar Islam dengan Sidi 'Abdul 'Aziz. Ia mengambil nama Sultan Muhammad Shah sebagai namanya. ${ }^{32}$ Sejak itu, semua raja Melaka menggunakan gelar Sultan dan Shah

${ }^{25}$ B.H.M. Vlekke, Nusantara A History of Indonesia. (The Hague and Bandung: Van Hoeve, 1943), 82.

${ }^{26}$ Muhammad Yusoff Hashim, Kesultanan Melayn Melaka (Kuala Lumpur: Dewan Bahasa dan Pustaka, 1990), 99. Lihat juga versi bahasa Inggris Muhammad Yusoff Hashim, The Malay Sultanate of Malacca, terjemah oleh D.J. Muzaffar Tate (Kuala Lumpur: Dewan Bahasa dan Pustaka, 1992)

${ }_{27}$ S. Q. Fatimi, Islam Comes To Malaysia (Singapore: Malaysian Sociological Research Institute, 1963), 87. "The Spread of Islam along the straits of Malacca was largely due in the first instance to marriages between members of royal..."

${ }^{28}$ Godinho De Eredia, Description of Malacca and Meridional India and Cathay, terjemah oleh J.V. Mills. (Kuala Lumpur: MBRAS, 1997), 4950. "...later (Islam) it was accepted and encouraged by permicuri at Malacca at the year 1411."

${ }^{29}$ C.O. Blagden, "Malacca", dalam Encyclopédie de l'Islam (Leiden dan Paris: E.J. Brill dan C. Klincksieck, 1936), 198-199.

${ }^{30}$ Raja ketiga Melaka. Ia menggantikan ayahnya pada 1423/1424 dengan nama Sri Maharaja, lihat Gungwu, "The First Three ..."

${ }^{31}$ Lanang, Sulalat al-Salatin...,50.

32Lanang, Sulalat al-Salatin...,51. 
untuk menyatukan kerajaan mereka ke dalam satu umat Islam (ummah islamiyyah). ${ }^{33}$ Raja yang memerintah selama 20 tahun itu (1424-1444) adalah seorang raja yang saleh. Sulalat al-Salatin menceritakan bahwa sang raja senantiasa pergi ke masjid untuk salah tarawih selama bulan Ramadan, merayakan bersama rakyatnya laylat al-qadr, 'id al-fitri, dan 'id al-adhä. ${ }^{34}$

Raja Ibrahim, anak dari Sultan Muhammad dan permaisuri, putri dari Rokan, menjadi sultan dengan nama Abū Shahid. Ia hanya memerintah selama dua tahun (1444-1446), korban kelicikan politik yang dirancang oleh saudara tirinya Raja Kasim, Maulana Jalaluddin, dan pamannya Tun Ali (Seri Nara Diraja). Setelah pembunuhannya, mereka mengangkat Raja Kasim sebagai raja. Ia adalah anak dari Sultan Muhammad dan Tun Wait. ${ }^{35}$ Saat penobatannya sebagai raja, Raja Kasim mengambil nama Sultan Muzaffar Shah. Ia adalah sultan yang menyuruh membuat undang-undang untuk mengatur Melaka. Sulalat alSalatin menjelaskan:

"Setelah Sultan Muzaffar Shah di atas kerajaan terlalulah baik fi'il baginda dengan adilnya dan murahnya dan saksamanya pada memeriksai segala ra'yat baginda. Syahadan ialah menyuruhkan menyurat kitab undang-undang supaya jangan lagi bersalahan segela hukum menterinya." 36

Undang-undang ${ }^{37}$ ini telah membuat, antara lain, Melaka menjadi pelabuhan sangat penting bagi para pedagang asing pada abad ke-15. UU tersebut telah memberikan keamanan, ketenangan, dan perlindungan kepada para pedagang ${ }^{38}$. UU itu juga mengatur perdagangan dengan cara yang memuaskan untuk

33Wilkinson, "The Malacca Sultanate," 28.

34 Lanang, Sulalat al-Salatin...,54-56, Adil, Sejarah Melaka...,22-23, Wilkinson, "The Malacca Sultanate," 30.

35 Lanang, Sulalat al-Salatin...,58-60, Wilkinson, "The Malacca Sultanate," 34.

36Lanang, Sulalat al-Salatin...,61.

${ }^{37}$ Diskusi mengenai undang-undang dapat dibaca lebih lanjut di bawah sub-bab ini.

38Barbara Watson Andaya dan Leonard Y. Andaya, A History of Malaysia (Honolulu: Univesity of Hawai'i Press, 2001), 44. 
para pedagang. ${ }^{39}$ Sultan Muzaffar Shah memperluas wilayah Melaka. Ia merebut Semenanjung Melayu dan sebagaian Sumatera, yaitu Pahang, Perak, Johor, Bintan, Siak, Indera Giri dan Kampar. ${ }^{40}$ Daerah-daerah ini diatur oleh undang-undang yang sama yang dikenal dengan namaUndang-Undang Melaka. ${ }^{41}$ Sulan menikah dengan Tun Kudu dan memerintah selama 10 tahun (1446-1456). Muzaffar Shah wafat pada 1456.

Anaknya, Sultan Abdul, menjadi raja setelah kematian ayahnya dan mengambil nama Sultan Mansur Shah. Ia menikahi Tun Putih Nur Alam, puteri Tun Ali. Mansur Shah, menurut Pirès, membangun masjid yang indah. ${ }^{42}$ Ia memerintah selama 21 tahun hingga wafat pada 1477.

Sultan Alauddin Riayat Shah menggantikan ayahnya Mansur Shah. Pada saat itulah, menurut Albuquerque, banyak orang berdatangan dari seantero dunia. Melaka berpenduduk 40.000 orang. ${ }^{43}$ Raja ini memerintah dari 1477 sampai 1488. Pemerintahannya terhenti secara tragis, karena ia diracun yang dirancang oleh para penguasa dari Pahang, Sultan Ahmad, dan Inderagiri, Raja Merlang, beberapa saat sebelum keberangkatannya ke Mekkah. ${ }^{44}$

Putranya, Sultan Mahmud, menggantikan Alauddin Riayat Shah. Sebelum ayahnya meninggal, Sultan Mahmud berlainan pendapat dengan ayahnya. Ia berkeberatan dengan rencana ayahnya yang akan berangkat ke Mekkah untuk berhaji. Ia mengatakan bahwa Mekkah yang sebenarnya adalah Melaka ${ }^{45}$.

39Jorge M. dos Santos Alves, "The Foreign Traders' Management in the Sultanates of the Straits of Malacca," dalam From The Mediterranean To The China Sea, disunting oleh Claude Guillot, Denys Lombard dan Roderick Ptak, 31-142 (Wiesbaden: Harrassowitz Verlag, 1998), 135.

40Pirès, The Suma Oriental...,242.

41Luis Filipe Ferreira Reis Thomaz, "The Malay Sultanate of Melaka," dans Southeast Asia in the Early Modern Era: Trade, Power, and Belief, édite par Anthony Reid, 69-90 (Ithaca and London: Cornell University Press, 1993), 79 .

42Pirès, The Suma Oriental..., 249.

${ }^{43}$ Albuquerque, The Commentaries of the Great ...,81.

44Pirès, The Suma Oriental..., 251, Albuquerque, The Commentaries of the Great ...,81, dan Adil, Sejarah Melaka...,51.

${ }^{45}$ Albuquerque, The Commentaries of the Great ...,82. 
Masa pemerintahannya sangat kejam. Menurut Albuquerque, ia membunuh saudaranya, Sulaiman, anaknya, Ahmad, 17 pembesar kerajaan, dan keluarga Bendahara. ${ }^{46}$ Kendati demikian, ia adalah sultan yang membuat dan memberlakukan UndangUndang Laut Malaka. ${ }^{47}$

Menurut sumber-sumber Portugis, Pirès dan Albuquerque, Sultan Mahmud Shah adalah sultan Melaka. Sebaliknya, Sulalat al-Salatin menegaskan bahwa sultan Melaka terakhir adalah Sultan Ahmad, putra Sultan Mahmud. Sulalat al-Salatin menceritakan:

"Hatta maka Sultan Mahmud Shah pun membuangkan kerajaan baginda. Maka anakanda baginda itu, Sultan Ahmad, dirajakan baginda. Maka segala pegawai dan alat kerajaan sekaliannya diserahkan baginda pada Sultan Ahmad. Maka Sultan Mahmud Shah pun diam ke Kayu Ara, Sang (Sura) juga teman baginda." 48

Saat penyerangan orang-orang Portugis, Sultan Mahmud Shah melarikan diri ke daerah Batu Hampar, sementara anaknya ke daerah Bentayan di mana ia membangun kota baru. Saat kotakota yang mereka diami untuk berlindung diserang oleh pasukan Portugis, mereka pun pergi ke daerah Muar, lalu ke Pahang. Sultan Mahmud membunuh anaknya sendiri, Sultan Ahmad. ${ }^{49}$

\section{Keadaan Politik Internasional dan Ekonomi dan Agama di Melaka}

Para penguasa Melaka sangat memperhatikan hubungan dengan kerajaan-kerajaan yang lain. Mereka memiliki hubungan yang baik dengan Tiongkok, sebagaimana sumber-sumber Tiongkok menyatakan. Tiongkok memiliki pengaruh sangat penting di Semenanjung Melayu. ${ }^{50}$ Tiga raja pertama Melaka

46Ibid., 83.

${ }^{47}$ R.O. Winstedt dan Joselin P.E. de Jong, "The Maritime Laws of Malacca," Journal of the Malayan Branch Royal Asiatic Society XXIX, no. III (1956): 22-59 dan 28-29.

48Lanang, Sulalat al-Salatin...,165.

${ }^{49}$ Lanang, Sulalat al-Salatin...,168-169.

${ }^{50}$ W. P. Groeneveldt, "Notes on the Malay Archipelago and Malacca Compiled Form Chinese Sources." Verhandelingen Van Het Bataviaasch Genootschap V an Kunsten En Wetenschappen XXXIX, no. I (1877):1-144. Untuk hubungan antara Tiongkok dan Semenanjung Melayu, lihat lebih khusus halaman 119-140. 
pernah pergi ke Tiongkok untuk menghadap kaisar dan menghantarkan hadiah sebagai upeti ${ }^{51}$. Bahkan, raja kedua Melaka, Iskandar Shah, menikahi puteri seorang raja Tiongkok yang bernama Puteri Raja Cina. Dari pernikahan tersebut, lahirlah raja-raja Kampar dan Pahang 52 .

Hubungan diplomatik dengan Tiongkok terus berlangsung hingga jatuhnya Melaka ke tangan Portugis. Menurut salah satu sumber Tiongkok, sekitar 60-an duta telah dikirim antara Melaka dan Tiongkok sepanjang 1403-1521.53 Melaka menggantikan Pasai sebagai pusat perdagangan. Melaka menjadi perempatan perdagangan antarbangsa yang besar dan lebih penting dari Sriwijaya sebelumnya ${ }^{54}$. Kebesaran Melaka dikenal berkat catatan Pirès :

"[...] Who doubt that in Malacca bahars of gold will be made, and that there will be no need of money from India, but it will go from here to there? And I do not speak of Banda and the Moluccas, because it is the easiest thing in the world for all the spices to reach there (India) without any trouble, because Malacca pays wages and maintenance, and it will make money, and will send all the spices if they are acquired and traded and controlled, and if it has the people such as it deserve $[\ldots]^{55}$

Pirès menceritakan kepada kita tentang kekayaan Melaka yang tak dapat dinilai :

"[...] Men cannot estimate the wroth of Malacca, on account of its greatness and profit $[\ldots]^{56}$

Pirès menyatakan bahwa Melaka adalah surga bagi para pedagang. Ia menulis:

"[...] Malacca is a city that was made for merchandise, fitter than any other in the world; the end of monsoons and the beginning of others.

51Vlekke, Nusantara A History...,82, Adil, Sejarab Melaka...,11-16.

${ }^{52}$ Albuquerque, The Commentaries of the Great ...,79 dan Pirès, The Suma Oriental...,246.

53Liang Liii, Hubungan Empayar Melaka-Dinasti Ming Abad ke-15 (Bangi: Universiti Kebangsaan Malaysia, 1996), 63-76.

${ }^{54}$ B. Schrieke, Indonesian Sociological Studies, 2 jilid (The Hague and Bandung: Van Hoeve, 1955 dan 1957), jilid I, 11 dan 17; jilid II, 260.

55Pirès, The Suma Oriental...,285-287.

56Pirès, The Suma Oriental.... Kekayaan Melaka juga dicatat oleh Eredia. Ia mengatakan kekayaan hewani dan nabati di awal abad ke-17, saat kunjungannya ke Melaka pada 1603, lihat Eredia, Description of Malacca...,17. 
Malacca is surrounded and lies in the middle and the trade and the commerce between the different nations for a thousand leagues on every hand must come to Malacca [...] [...] whoever is lord of Malacca has his hand on the throat of Venice. ...who understand this will favour Malacca; let it not be forgotten $[\ldots]^{57}$

Pirès mengatakan juga bahwa tidak ada yang bisa menandingi Melaka di dunia ini :

"[...] There is no doubt that Malacca is of such importance and profit that is seems to me it has no equal in the world." 58

Melaka juga dikenal dengan kekayaan sumber daya alamnya. Menurut Pirès, di Melaka orang dapat menemukanbawang puting, bawang merah, kapur barus ${ }^{59}$; menurut Albuquerque,j agung, sutera, brokat, batu tawas, porselen, kuningan, emas dan perak, ${ }^{60}$ dan, menurut Vasco Da Gama (1498), sutera, tembaga, porselen, dan cengkeh. ${ }^{61}$ Seorang Portugis lainnya, Duarte Barbosa pada 1518 telah bersaksi tentang keindahan dan kekayaan Melaka:

"Through the sea of this city of Malacca there is along the coast a string of many beautiful islands, very rich and fertile of Moors and Heathen (besides other small peoples which dwell there)..." ${ }^{62}$

Selain sebagai pusat perdagangan, Melaka juga menjadi, setelah Pasai, pusat penyebaran Islam pada abad ke-15. Penyebaran agama Islam mengikuti jalur perdagangan. ${ }^{63}$ Melaka berperan dalam islamisasi Semenanjung Melayu, Sumatera Timur ${ }^{64}$, bagian Barat Nusantara seperti Borneo dan Sulawesi. Di Melaka, para ulama datang dari Arab dan Persia, mengajarkan Islam. Sulalat al-Salatin menjelaskan bahwa ada seorang ulama,

57Pirès, The Suma Oriental...

${ }^{58}$ Ibid., 285.

59Ibid dan Shcrieke, Indonesian Sociological..., jilid I, 263.

${ }^{60}$ Albuquerque, The Commentaries of the Great ...,88.

${ }^{61}$ Ferrand, Malaka: Le Malayu...,20.

62Duarte Barbosa, The Book of Duarte Barbosa 1512, diterjemahkan dari teks Portugis edisi 1812 oleh Mansel Longworth Dames, jilid 2 (London: The Hakluyt Society, 1921), 180.

63Vlekke, Nusantara A History...,82.

${ }^{64}$ Anthony Reid, Southeast Asia in the Age of Commerce 1450-1680, 2 jilid (New Haven and London: Yale University Press, 1988), jilid I, 133. 
Maulana Sadar Jahan, memberi pengajaran agama kepada sultan dan para pembesar istana. ${ }^{65}$ Bahkan, Sunang Bonang dan Sunan Giri mendapatkan pelajaran (wejangan), menurut murid Sunan Bonang, Sunan Kali Jogo, dari Cheikh Sutabris di Pulo Upih, daerah Jawa di Melaka. ${ }^{6}$ Menurut Claude Guillot, Cheikh Sutabris adalah Shams al-Dīn al-Tabrīzì atau Shams-i Tabrīz, salah satu ulama Persia terkenal dan sangat dihormati di Nusantara. Ia menyuruh kepada dua wali dari Jawa ini untuk kembali ke Jawa untuk mengajarkan tasawuf. ${ }^{67}$

\section{Pembahasan}

\section{Undang-Undang Melaka: Undang-Undang Pertama di Nusantara}

Kajian teks atas naskah UUM telah dikaji dengan baik oleh Liaw Yock Fang dengan pendekatan Filologi untuk tesis doktoralnya di Universitas Leiden. Tesis tersebut kemudian diterbitkan dengan judul Undang-Undang Melaka. ${ }^{68}$ Kami akan merujuk pada buku tersebut untuk menganalisis isi teks UUM dengan pendekatan hukum, satu pendekatan yang tidak digunakan oleh Liaw Yock Fang. Kami akan menggunakan alihaksara dalam bahasa Melayu dan terjemahan teks UUM dalam bahasa Inggris.

Pertama-tama, kami akan menganalisis apa yang dimaksud dengan undang-undang di sini. Apakah kata Undang-Undang disebutkan di dalam teks? Kami tidak menemukan sama sekali kata tersebut di dalam teks. Namun demikian, kita sudah lihat bahwa di dalam Sulalat al-Salatin menyatakan dengan jelas bahwa Sultan Muzaffar Shah memerintahkan untuk menuliskan UndangUndang. ${ }^{69}$ Apa yang kami temukan di dalam teks UUM adalah

65 Lanang, Sulalat al-Salatin...,152-153, dan 166. "Sebermula akan Sultan Mabmud Shah senantiasa baginda mengaji pada Makbdum Sadar Jahan."

6rSchrieke, Indonesian Sociological...,jilid II, 261-262.

${ }^{67}$ Claude Guillot, "La perse et le Monde malais. Echanges commerciaux et intellectuels," Archipel 68 (2004):59-192 dan 181-182. Menurut Sejarah Banten, Syamsu Tabris adalah anak hasil hubungan sedarah antara ayah dan anak perempuannya, lihat Hoesein Djajadiningrat, Tinjauan Kritis Tentang Sejarah Banten (Jakarta: Djambatan, 1983), 27-29. 1976)

${ }^{68}$ Liaw Yock Fang, Undang-Undang Melaka (The Hague: M. Nijhoff,

${ }^{69}$ Lanang, Sulalat al-Salatin...,61. 
kata bukum kanun di dalam pendahuluan UU tersebut. ${ }^{70} \mathrm{Hukum}$ adalah kata yang berasalah dari bahasa Arab yang berarti hukum atau keputusan (al-qadā). ${ }^{71}$ Kanun bukan kata Arab, tetapi serupa dengan bahasa Arab yang berarti dasar (așl, jamak: uṣūl) ${ }^{72}$, undang-undang, kitab hukum, atau hukum. ${ }^{73}$ Menurut Liaw Yock Fang, katakanun, pada saat itu, berarti hukum adat ${ }^{74}$ yang bermakna adat setempat di mana teks tersebut ditulis. Hal itu berarti UUM adalah satu teks hukum adat di Melaka abad ke-15. Pertanyaan yang muncul di sini adalah mengetahui apakah hukum adat tertulis itu suatu undang-undang atau bukan. Oleh karena itu, harus diartikan terlebih dahulu apakah undangundang itu?

Definisi tentang undang-undang, menurut Jean Gaudemet, tidaklah pasti. ${ }^{75}$ Franz Wieacker pada 1954 mendefinisikan undang-undang sebagai "peraturan yang lengkap yang mencakup keseluruhan atau sebagian cabang dari hukum". Dengan pengertian tersebut, ia berarti suatu karya yang mempunyai nilai 'pengatur'. Beberapa tahun berikutnya, Jacques Vanderlinden pada 1967 mendefinisikan undang-undang sebagai "suatu proses pembukuan hukum (kodifikasi) yang mengumpulkan semua perihal berbeda". ${ }^{76}$ Dengan demikian, ia hanya menyatukan berbagai teks hukum. ${ }^{77}$ Bagi Gaudemet sendiri, undang-undang adalah karya hukum yang terdiri dari satu kesatuan normanorma wajib yang ditulis dalam satu redaksi dan membahas beragam masalah. ${ }^{78}$

${ }^{70}$ Fang, Undang-Undang Melaka, 62.

${ }^{71}$ Ibn Manzhūr, Lisan al-'Arab, jilid II, h. 951-952.

${ }^{72}$ Ibid., jilid V, 3759.

73Daniel Reig, Dictionnaire Arabe Français, Français Arabe (Paris : Larouse, 1983), 4375.

74Fang, Undang-Undang Melaka, 178.

${ }^{75}$ Jean Gaudemet, "Codes, Collections, Compilations Les Leçons de l'Histoire. De Grégorius A Jean Chappuis," Droits 24, no. La Codification I (1996): 3-16 dan 4.

${ }^{76}$ Jacques Vanderlinden, Le concept de code en Europe occidentale du XIIIe au XIXe siècle. Essai de définition (Bruxelles: Editions de l'Institut de Sociologie, 1967), dikutip dalam Gaudemet, "Codes, Collections,... "

${ }^{77}$ Gaudemet, "Codes, Collections,..."

${ }^{78}$ Gaudemat, "Codes, Collections,... , ,15. 
Kemudian, apakah hukum adat tertulis adalah suatu undangundang? Gaudemet melihat bahwa semua hukum adat yang ditulis sampai abad ke-17 tidaklah masuk dalam pengertian tersebut.Mulai abad ke-18, undang-undang benar-benar menjadi suatu akta hukum dengan mempertimbangkan pemikiran tentang 'kodifikasi' yang berkembang. ${ }^{79}$ Artinya, hukum adat tertulis itu bukan undang-undang.

Sebaliknya, Jean-Louis Gazzaniga tidak setuju dengan pendapat tersebut. ${ }^{80}$ Ia menjelaskan bahwa sebagian besar sejarawan hukum tidak mengakui nilai undang-undang yang berasal dari hukum adat tertulis, karena beberapa alasan. Pertama, penulisan hukum adat itu tidak sistematis. Kedua, hukum adat itu tidak lengkap dalam hukum pidana dan bahkan dalam hukum acara. Ketiga, sebagian besar hukum adat ditulis tanpa rencana dan tanpa aturan. ${ }^{81}$ Gazzaniga menolak alasan-alasan tersebut.Ia mengatakan bahwa jika istilah 'kodifikasi' merujuk pada undangundang dalam pengertian à la Napoleon Bonaparte, maka hukum adat tertulis tidak masuk dalam definisi tersebut. Demikian juga, jika undang-undang hanya merupakan kesatuan hukum dan lengkap, maka hukum adat tertulis bukanlah undang-undang. Gazzaninga menjelaskan bahwa penulisan resmi hukum adat menunjukkan adanya 'satu konsep tertentu tentang hukum dan negara, aturan umum untuk mempermudah pengetahuan dan menyederhanakan penerapan aturan, membatas aturan dan menentukan hukum sedapat yang kita lakukan, maka kita dapat bicara tentang kodifikasi'. ${ }^{82}$

Undang-Undang Melaka adalah UU pertama yang diberlakukan dan dikenal di Nusantara. Teks UUM menjelaskan bahwa Sultan Muhammad Shah (1424-1444) adalah raja yang mengatur hukum adat. ${ }^{83}$ Tetapi, pada masa tersebut, hukum adat belum ditulis. Baru pada masa Sultan Muzaffar Shah (1445-

${ }^{79}$ Ibid.,14.

${ }^{80}$ Jean-Louis Gazzaniga, "Rédaction des Coutumes et Codification," Droits 26, no. La Codification II (1997): 71-80.

${ }^{81}$ Ibid., 79 .

82Ibid., 80.

${ }^{83}$ Fang, Undang-Undang Melaka, 64. 
1456), hukum adat itu ditulis dan menjadi undang-undang. ${ }^{84}$ UUM banyak memengaruhi undang-undang di kesultanan lainnya di Nusantara, yaitu Kedah, Pahang, Johor, Riau, Pontianak ${ }^{85}$ and Bima. ${ }^{86}$ Undang-Undang Laut Malaka ditulis pada masa Sultan Mahmud Shah (1488-1511). ${ }^{87}$

Teks UUM, sesungguhnya, meliputi 6 undang-undang, yaitu UUM yang sebenarnya (pasal 1-23.1), sebagian Undang-Undang Laut Malaka (pasal 23.3-5, 24.1-2 dan 29), Undang-Undang Pernikahan Islam (pasal 25-28), Undang-Undang Perdagangan Muslim (pasal 30-42 dan 43.1), Undang-Undang Negeri (pasal 43.28, 44.1-8) dan Undang-Undang Johor (pasal 44.9-11). UUM mencakup 44 bab dan 128 pasal. Kami akan menganalisis bagian UUM yang sebenarnya, sementara kami akan kesampingkan Undang-Undang Negeri dan Undang-Undang Johor, karena kedua undang-undang tersebut tidak termasuk UUM yang sesungguhnya.

Dengan demikian, UUM yang sebenarnya mengandung 4 undang-undang dan 110 pasal. Di dalamnya, terdapat hukum adat, hukum Islam, dan hukum campuran antara keduanya. Pasal-pasal tersebut sangat jelas membedakan antara hukum adat dan hukum Islam. Jika pasal-pasal itu menyebutkan dengan jelas 'menurut hukum syara', maka pasal tersebut berasal dari hukum Islam. Sebaliknya, jika hukum Allah tidak disebut, maka pasal tersebut berasal dari hukum adat. Hampir semua pasal, kecuali yang terkait dengan hukum pernikahan, menyajikan dan mengajukan hukum adat, kemudian hukum Islam. Hukum Islam menjadi hukum alternatif dari hukum adat dalam semua aspek hukum, kecuali hukum pernikahan. Antara kedua hukum ini, terdapat jenis hukum ketiga, yaitu, hukum campuran antara hukum adat dan hukum Islam.

Kami melihat bahwa dari 110 pasal di dalam UUM, sebanyak 70 pasal (77\%) merupakan hukum adat yang melingkupi hukum perdata, hukum pidana, dan hukum dagang;

84Ibid., 64 dan 178. Lanang, Sulalat al-Salatin...,61

85Fang, Undang-Undang Melaka, 2.

86Henry Chambert-Loir et Siti Maryam R. Salahudin, (ed.) Bo' Sangaji Kai: Catatan Kerajaan Bima (Jakarta: EFEO\&YOI, 2000), 93-108.

${ }^{87} \mathrm{~W}$ instedt dan de Jong, "The Maritime Laws...," 28-29. 
38 pasal merupakan hukum Islam (41,8\%) yang hampir semuanya adalah hukum pernikahan, dan 2 pasal merupakan hukum campuran $(2,2 \%)$ dari keduanya. 38 pasal, yang mengandung hukum Islam, selalu menyebutkan hukum adat, kecuali untuk hukum pernikahan. Sekarang, kami akan mengungkapkan dan menganalisisisi pasal-pasal yang mengandung hukum Islam, yaitu hukum pernikahan.

\section{Hukum Perkawinan di dalam UUM}

Menurut Liaw Yock Fang, hukum perkawinan di dalam UUM adalah hukum Islam menurut mazhab Shāfíī berdasarkan kitab fikih karangan Abū Shujā $\bar{a}^{6}$ dan penjelasannya. ${ }^{88}$ Para sarjana dan peneliti mengutip pendapat tersebut tanpa mempertanyakan kembali. Di dalam artikel ini, kami akan menguji ulang jika hukum perkawinan di dalam UUM adalah apakah benar hukum Islam mazhab Shāfi' $\overline{1}$ atau ia juga mengandung pendapat mazhab-mazhab fikih. UUM mengatur beragam masalah di dalam hukum perkawinan, seperti wali, ijābqabūl, saksi, talak, dan hak membatalkan (khiyär). Di bawah ini, kita akan membahas satu persatu persoalan tersebut.

\section{Wali}

Yang terkait dengan masalah perwalian, pasal 25.1 UUMberbunyi :

"Apabila ada perempuan itu berbapa atau bernenek atau bersaudar lakilaki, itulah akan walinya perempuan itu. Jikalau ada anaknya bikir, maka tiadalah menjadi syarat pada bertanya redanya itu. Adapun jikalau bikirnya itu besar ya'ni 'akil balig, maka sunat ditanya redanya, tetapi jikalau tiada ditanya pun harus hanya tiada beroleh sunat pada suatu kaul azhar. Adapun akan nenenknya itu daripada pihak laki-laki, harus bersuamikan dengan tiada (redanya) anak perempuan yang bikir itu iaitu daripada cucunya, karena bagi(nya) neneknya itu wali mujbir. Adapun mujbir itu iaitu yang dapat menggagahi, itulah artinya mujbir. Adapun akan anak perempuan (bahu) itu maulah ia dengan izinnya juga, maka harus dipersuamikan akan dia, karena izinnya itu syarat bagi sah kawinnya itu. Adapun (thayyib)yang kecil iaitu belum lagi baligh. Jikalau belum baligh tiada sah bagi bapanya dan neneknya bersuamikan dia, jikalau ada dengan izinnya sekalipun, tiada dapat dinikahkan dengan laki-laki itu. Demikianlah hukumnya melainkan dinantikan hingga

${ }^{88}$ Fang, Undang-Undang Melaka, 33. 
baligh hukumnya itulah maka harus dipersuamikan itu pada suatu kaul yang sah.Adapun syarat baligh itu tiga perkara. Suatu genap 'umurnya lima belas tahun, kedua dengan ada haid, ketiga ada ibtilam, artinya sampai ada tumbuh bulu ari-arinya, itupun belum mu'tamad. Itulah 'alamat baligh itu. Adapun pada hukum wali itu, sama ada bapa perempuan dan neneknya perempuan itu daripada pihak laki-laki itu, kedua itulah yang bernama wali mujbir. Adapun akan saudaranya dan bapanya dan neneknya itu wali akrab namanya, artinya akrab itu iaitu keluarga yang hampir juga, harus mereka itu akan wali. Adapun jikalau tiada wali akrab dan wali mujbir, maka haruslah hakim akan walinya.Adapun syarat hakim akan wali itu : tatkala tiada diperoleh wali akrab; kedua jauh wali itu daripada negeri, kira-kira ada sehari semalam genap hingga (safratu'l-kasr) namanya. Dan jauh negeri itu dengan wali perempuan itu, maka harus hakim akan walinya. Ketiga tiada ada perempuan itu keluarganya iaitu yatim piatu, itupun hakim juga akan walinya.Adapun jikalau hasillah segala syarat yang tersebut itu, maka ia berlaku nikahnya itu kepada kitab Allah ta'ala."89

Pasal tersebut menjelaskan dua syarat pernikahan: persetujuan/izin perempuan yang akan menikah dan penentuan wali yang berhak menikahkannya.

Hukum Islam (fikih) membedakan antara perempuan yang masih kecil dan perempuan yang sudah dewasa. Menurut Shāfís ${ }^{\circ}$, wali tidak dapat menikahkan anak perempuan, baik kecil maupun dewasa, tanpa persetujuannya/izinnya. Kendati demikian, seorang ayah memiliki hak memaksa putrinya untuk menikah. ${ }^{90}$ Abū Shujā' menjelaskan pandangan yang serupa dengan Imam Shāfíci, yaitu diperbolehkan bagi wali (ayah atau kakek) menikahkan anak perempuan yang masih belum dewasa (balig). ${ }^{91}$ Sebaliknya, Abū Hanīah dan al-Awzā'̄ menjelaskan bahwa menikahkan seorang anak perempuan kecil oleh walinya adalah sah walaupun tanpa persetujuannya. Jika anak perempuan itu telah dewasa (balig), ia dapat memilih antara meneruskan pernikahannya atau membatalkannya. ${ }^{92}$ Akan tetapi, jika ayah atau kakeknya yang menikahkannya, ia tidak berhak

${ }^{89}$ Ibid., 126-128.

${ }^{90}$ al-Shāfi'i, Al-Umm, jilid III, 17-18. Lihat juga J. Schacht, "Nikāh," dalam Encyclopédie de l'Islam (Leiden: E.J. Brill, 1995), 26-29.

${ }^{91}$ al-Sharbīnī, al-Iqnā' Fì Halli..., jilid II, 582.

${ }^{92}$ Sābiq, Fiqh Sunna, jilid II, 116. 
membatalkan pernikahannya. ${ }^{93}$ Adapun pernikahan seorang janda tidak akan pernah sah tanpa persetujuannya. ${ }^{94}$ Dengan membandingkan antara pasal tersebut dan kitab fikih, maka pasal tersebut, menurut kami, sudah sesuai dengan mazhab Shāfi'ī.

Terkait perihal wali, pasal tersebut menyatakan dengan jelas bahwa wali aqrab atau wali mujbir adalah bapak dan kakek anak perempuan itu. Di dalam hukum Islam, wāli mugbiradalah wali yang berwenang menikahkan anak perempuannya dengan paksaan, artinya tanpa persetujuannya. ${ }^{95}$ Pendapat antara mazhab berbeda-beda mengenai perihal terkait. Mazhab Hanafi berpendapat bahwa semua wali adalah wali mujbir. Mazhab Mālikī dan Hanbālī mengatakan bahwa wali mujbir adalah bapak saja. ${ }^{96}$ Berdasarkan keterangan tersebut, tampak bahwa pasal tersebut di atas merujuk kepada penafziran mazhab Shāfíi yang melihat bahwa wali mujbir adalah bapak atau kakek. ${ }^{97}$ Ketika tidak ada wali, pasal itu mengatakan bahwa hakim dapat bertindak sebagai wali dari perempuan yang belum dewasa itu. Hal ini jelas merujuk pada pendapat mazhab Shāfi ‘̄i. ${ }^{98}$

\section{Ijab-Kabul}

UUM menempatkan perihal ijab kabul di dalam pasal 25.2 :

"Adapun syarat kaul pada lafaz ijab kabul itu pada kahwin itu. Adapun artinya ijab kabul itu adalah seperti dikata oleh walinya itu: "Kupersuamikanlah anakku si anu itu akan isteri dikau." Maka jawab mempelai itu seperti yang tersebut di dalam hadith mengatakan 'Kabiltu tazwijaha' ya'ni telah kuterima ia akan isteriku. Itulah ijab kabul namanya. Adapun jikalau ada bapanya perempuan itu fasik iaitu seperti zinah dan minum arak dan tuak atau baang sebagainya pekerjaan yang haram, itupun tiada harus akan walinya itu. Adapuan pada suatu kauw dan suatu wajah, tiada dapat eprempuan itu berwali kepada saudaranya yang fasik melainkan hakim walinya maka sah".

${ }^{93}$ al-Gazīrī, Kitāb al-Fiqh...,jilid IV, 30.

94al-Sharbīn̄i, al-Iqnā' Fì Halli...,jilid II, 583; Sābiq, Fiqh Sunna, jilid II, 115.

${ }^{95}$ al-Gazìrī, op.cit., jilid IV, h. 28-29.

${ }^{96}$ Ibid., 29-30.

${ }^{97}$ al-Sharbīn̄i, Kitāb al-Fiqh..., jilid II, 578.

${ }^{98}$ Ibid., jilid II, 579 . 
Di dalam pasal itu, ada dua hal yang harus dikaji : pertama hal ijab-kabul dan kedua hal wali fasik. Hal yang terkait dengan ijab qabul, para fukaha setuju bahwa agar pernikahan dinilai sah, maka di dalam pelaksanaan pernikahan itu harus terselenggara ijab-kabul. ${ }^{99}$ Adapun perihal wali fasik, menurut mazhab Shāfí' $\overline{1}$, ia tidak berhak menikahkan anak perempuannya dan akibat itu haknya hilang. Lalu, hak untuk menikahkan perempuan itu tidak langsung jatuh ke tangan hakim, tetapi kepada wali $a b^{\prime} a d$ atau wali jauh. Namun, mazhab Hanafì dan Hanbālī tidak mengatakan bahwa wali fasik kehilangan hak untuk menikahkan anak perempuannya. ${ }^{100}$ Dengan keterangan ini, menurut kami, pasal tersebut jelas mengikuti mazhab Shāfi ${ }^{\top} \overline{1}$.

\section{Saksi}

Untuk keabsahan satu pernikahan, pasal 26 UUM mengatur perihal saksi:

"Adapun sekurang-kurang syaksi pada kahwin itu empat orang, tetapi jikalau tiada empat, dua orang pun padalah. Jikalau kurang daripada dua orang, maka iaitu zina(h), tiada sah nikahnya itu. Adapun orang yang boleh menjadi syaksi itu orang yang salih dan laki-laki yang 'adal lagi 'akil mursyid dengan merdehika. Jikalau tiada salih atau 'abdi atau perempuan tiadalah sah saksinya itu melainkan atas dua jalan jua : suatu syaksi haid, kedua syaksi akan hamil tiada lagi lain daripada itu. Adapun akan kahwin itu tiada harus bersyaksi kepada 'abdi atau orang yang fasik atau perempuan atas kaul azhar, adapun artinya pada ma'na nyata. Itu syaksi hukumnya."

\section{Pasal 37 (ayat 1) mengatur perihal yang sama tentang saksi:}

"Pada menyatakan hukum syaksi yang harusnya di atas empat martabat. Pertama tahu ia akan halal dan haram, kedua tahu ia akan sunat dan fardu, ketiga tahu ia akan salah dan benar, keempat tahu ia akan baik dan jahat. Itulah harus diperbuat syaksi. Syaksi tiada dikabulkan melainkan berhimpun pada syaksi itu lima pertara. Pertama Islam, kedua bligh, ketiga 'akil, keempat 'adal, kelima hendaklah menjauhi daripada dosa yang besar dan dosa yang kecil, dan baik kelakukannya dan jangan ia penggusar dan memliharkan lakunya dan namanya."

Pasal 26 dan 37 (1) mengatur soal saksi dalam pernikahan dan syarat yang harus dipenuhi untuk menjadi seorang saksi.

${ }_{99}$ al-Gazìirī, Kitäb al-Fiqh...,jilid IV, 12.

${ }^{100}$ Ibid., jilid IV, 39-41, al-Sharbīnī, al-Iqnā' Fì Halli..., jilid II, 579. 
Mazhab Mālikī, Shāfíī, dan Hanbālī berpendapat bahwa pernikahan dinilai sah jika disaksikan oleh dua saksi lelaki. ${ }^{101}$ Syarat yang harus dipenuhi oleh seseorang agar kesaksiannya diterima adalah: berakal (aqi) dan dewasa (balig/murshid) ${ }^{102}$. Fukaha Shāfíi dan Hanbālī menambah satu syarat lagi, yaitu seorang saksi harus adil (adil). Akan tetapi, fukaha Hanafi mengatakan bahwa tidaklah wajib seorang saksi itu adil (adb). ${ }^{103}$ Pasal tersebut merujuk pada pendapat fukaha Shāfi $\overline{1}^{\top}$, Hanbālī, dan Mālikī.

Pasal 37.2 UUM membahas tentang tata-cara kesaksian secara umum:

"Bermula tiada pada zinah itu thabit melainkan empat orang laki-laki dan jikalau tiada empat melainkan dua orang laki-laki pada segala hadd seperti minum arak dan tuak dan mencuri dan menyamun dan membunuh orang dan murtad dan kisas pada nyawa dan pada anggota dan orang bermuka(h)-muka(h) dan ikrar pada segala perkara ini dan nikah dan talak dan meredeka dan Islam dan pada amanat dan pada wakil dan pada wasiat dan ikrar pada segala perkara ini dan melihat bulan Ramadhan dengan seorang pun padalah. Bermula tiada thabit melainkan dua laki-laki atau seorang laki-laki dengan dua perempuan. Tiada thabti dengan perempuan sebanyak-banyaknya pada berniaga dan berpulangan dan mengalikan benda yang dibeli; jikalau < berjual dan bersandar $>$ pada jual dan pada mengaku dan pada sulh dan melepaskan dan pada utang dan meminjam dan pada upahan dan sekutu dan pada memberi dan merampas dan pada membinasakan. Bermula tiada thabit melainkan dua orang laki-laki atau seorang laki-laki dan dua orang perempuan atau empat orang perempuan pada beranak dan bikir dan $<$ thayyib> ya'ni janda dan segala <'aib> perempuan dan segala yang banyak pekerjaan dan segala perempuan mengetahui dia." 104

Apa yang menjadi perhatian kita di dalam pasal itu adalah jumlah saksi. Kita tidak akan masuk ke dalam rincian pasal tersebut. Pasal di atas secara jelas menyebutkan bahwa kesaksian harus dilakukan oleh dua orang lelaki atau tiga orang: seorang lelaki dan dua perempuan. Tiga mazhab fikih: Mālikī, Shāfí'í, dan Hanbālī setuju memberikan hak istimewa kepada lelaki untuk bersaksi. Sebaliknya, mazhab Hanafi berpendapat bahwa seorang

101Ibid., jilid IV, 25.

102Sābiq, Figh Sunna, jilid II, 50.

103al-Gazīrī, Kitāb al-Fiqh..., jilid IV, 25; Sābiq, Fiqh Sunna, jilid II, 50.

${ }^{104}$ Fang, Undang-Undang Melaka, 150-152. 
perempuan dapat bersaksi dengan kehadiran seorang lelaki. Dengan demikian, kesaksian dua perempuan dan seorang lelaki, menurut mazhab Hanafi, adalah sah. ${ }^{105}$ Teks di dalam pasal itu merujuk kepada semua pendapat mazhab.

\section{Hukum Pembatalan}

Jika sepasang suami-istri mempunyai masalah dalam pernikahan, karena suatu penyakit yang diderita salah satunya, maka yang satunya lagi selalu mempunya hak untuk membatalkan (khiyar). Pasal 27 UUM mengatur hukum pembatalan. Pasal itu menyatakan :

"Pada menyatakan hukum khiyar itu mau pada perempuan, mau pada laki-laki itu atas lima perkara 'aibnya itu, pertama-tama 'aib gila (dan) judham, kedua baras, ya'ni sopak atau kedal, ketiga 'aib ratak, keempat 'aib karan, ya'ni tumbuh tulang pada perjinya, kelima 'aib kediri (dan) orang yang lemah zakarnya iaitu seperti orang ratak hukumnya, dan judham pun demikian juga, tiada sah nikahnya kahwin dengan orang yang demikian itu. Adapun jikalau dikahwinkan orang suatu laki-laki maka tiada diberinya tahu akan hal ada perempuan itu berpenyakit yang demikian itu. Telah kemudian, maka baharu diketahuinya, niscaya terurailah kahwinnya itu ya'ni <faskh>, tiadalah laki-laki itu menanggung isi kahwin perempuan. Dan demikian lagi, jikalau ada 'aib laki-laki yang berpenyakit seperti yang tersebut itu, maka itupun $<$ faskh $>$ jua, jikalau tiada kabul perempuan itu, diberitahukannya kepada hakim, niscaya cerai jua. Jika lemah zakarnya laki-laki itu, maka disuruh oleh hakim berubat kepada tabib yang tahu, maka dinantikan setahun lamanya. Jikalau tiada sembuh di dalam setahun, maka $<$ faskh $>$ nikahnya itu. Adapun akan orang yang baras dan judham dan gila itu : jikalau reda perempuan itu akan laki-laki itu atau reda laki-laki itu akan perempuan itu, tiadalah ia <difaskhkan> oleh hakim akan mereka itu, karena sama reda keduanya ya'ni ia suka keduanya, tiada lagi khiyar daripada yang demikian itu, itu kaul yang sah. Adapun jikalau diperoleh 'aib tatkala di dalam laki-laki, difaskhkannya dirinya perempuan itu atas isi kahwinnya akan laki-laki itu. Demikian lagi jikalau ada 'aib laki-laki itu di dalam perempuan itu, itupun difaskhkan dirinya daripada perempuan itu. Demikian lagi atas barang yang diperoleh 'aib di dalam sudah kahwin, itupun faksh jua. Itulah hukum khiyar atas tiap-tiap kahwin. Demikianlah hukumnya itu."106

105al-Gazìrī, Kitäb al-Fiqh..., jilid IV, 25.

106Fang, Undang-Undang Melaka, 130. 
Pasal di atas menjelaskan alasan-alasan pembatalan pernikahan. Tampak jelas, bahwa alasan-alasan tersebut berasal dari hukum Islam. Hukum Islam membicarakan perihal penyakit yang setiap pasangan dapat membatalkan pernikahannya (faskb). Alasan-alasan yang membolehkan pembatalan pernikahan tersebut, pertama-tama, menyangkut pasangan suami-istri (sakit jiwa, lepra, dan penyakit gajah), kemudian hanya lelaki (lemah zakar atau tidak ada kepala zakar), lalu hanya perempuan (ratak, daging tumbuh di farji yang menghalangi jimak, dan karan, pertambahan ukuran tulang farji yang menghalangi jimak). ${ }^{107}$ Kami melihat bahwa pengaruh mazhab Shāfís dalam pasal 27 sangat penting.

\section{Talak}

Hal yang terkait dengan talak, pasal 28.1 mengaturnya:

"Adapun talak itu ada dua perkara: pertama, talak ba'in namanya; kedua talak raj'i namanya. Adapun talak ba'in itu seperti talak yang tiada lagi akan kembali iaitu seperti talak tiga. Adapun talak raji itu seperti talak satu atau talak dua, maka iaitu dapat kembali lagi.» adapun jikalau talak seorang perempuan dengan talak tiga itu, tiadalah dapat kembali lagi. Jikalau ia hendak kembali juga, dikahwinkan dengan laki-laki yang lain daripada suaminya yang dahulu itu. Kemudian talak ia dengan permepuan itu, maka díiddahkan dengan 'adat tiga bulan sepuluh hari. Sudah itu, maka dinikahkan dengan suaminya yang lama itu. Adapun talak raji itu iaitu seperti seorang perempuan ditalak oleh suaminya dengan talak sa(tu) atau dua, iaitu adalah 'iddahnya daripada tiga bulan sepuluh hari; jikalau ada laki-laki itu hendak kembali, hanya kahwin juga namanya, haruslah ia kembali. Maka tiada seperti talak ba'in itu." 108

Semua mazhab sepakat bahwa hanya ada dua jenis talak: raj'i dan bain. Talak raj'i adalah talak yang dijatuhkan oleh suami di mana suami dapat kembali lagi ke mantan isterinya, jika ucapan talaknya itu talak satu atau dua. Talak ba'in adalah talak ketiga yang mana suami tidak dapat kembali ke mantan isterinya, kecuali jika mantan isterinya itu sudah menikah dengan lelaki lain dan sudah melakukan hubungan badan, lalu suami baru itu

${ }^{107}$ al-Gazīrī, Kitāb al-Figh...,jilid IV, 180-198.

108Fang, Undang-Undang Melaka, 132. 
menceraikannya.Jika demikian, maka suami pertama dapat kembali menikahi mantan isterinya. ${ }^{109}$

\section{Pernikahan dengan Non-Muslim}

Pasal 28.2 mengatur perihal pernikahan dengan non-muslim:

"Demikian lagi harus kahwin dengan perempuan majusi dan kafir yang sudah diislamkan dan (tiada) harus kahwin dengan perempuan $<$ wathani $>$ pada kaul yang sah. Adapun bagai laki-laki itu haruslah ia mencari perempuan yang ahlul kitab pada hukum Allah ta'ala."110

Empat mazhab hukum Islam: Hanafī, Mālikī, Shāfícín, dan Hanbālī, bersepakat bahwa lelaki muslim dapat menikahi perempuan non-muslimah. Akan tetapi, lelaki non-muslim tidak bisa menikahi perempuan muslima. ${ }^{111}$

Para fukaha berbeda pendapat mengenai Majusi (Zoroaster): apakah mereka termasuk ahlul kitab atau bukan? Menurut Abū Thaur, Zoroaster termasuk kategori ahlul kitab, karena mereka menerima untuk membayar jizyah seperti Yahudi dan Nasrani ${ }^{112}$. Menurut Daud Zāhiri, Zoroaster termasuk golongan ahlul kitab, karena itu lelaki muslim memiliki kemungkinan menikahi perempuan Zoroaster, sebagaimana dengan perempuan ahlul kitab (Yahudi dan Nasrani). ${ }^{113}$ Akan tetapi, menurut fukaha Shāfi ‘̄i dan Hanbālī berpendapat bahwa Majusi tidak termasuk golongan ahlul kitab. ${ }^{114}$ Imam Shāfín menyatakan dengan jelas bahwa tidak diperbolehkan menikahi perempuan Majusi. ${ }^{115}$ Adapun yang terkait dengan pernikahan perempuan penyembah berhala (watsani), hukum Islam melarangnya. ${ }^{116}$

${ }^{109}$ Ibn Rushd, Bidāya al-MuGtabid...,jilid II, 45-46, al-Gazīrī, Kitāb alFiqh..., jilid IV, 316-320, al-Sharbīnī, al-Iqnā' FìHalli.., jilid II, 627-630.

110Fang, Undang-Undang Melaka, 132.

111al-Sarahsi, al-Mabsüt, jilid V, 38 dan 50; al-Shafi'i, al-Umm, jilid. IV, 182 dan 269, jilid. V, 6, 7, 269; Sābiq, Fiqh Sunna, jilid II, 90-94.

112Sābiq, Fiqh Sunna, jilid. II, 92.

113al-Gazīin̄, Kitāb al-Fiqh..., jilid VI, 75

${ }^{114}$ Sābiq, Fiqh Sunna, jilid II, 93.

115al-Shāfi'i, Fiqh Sunna, jilid IV, 182.

116Ibid., jilid IV, 182; Sābiq, Fiqh Sunna, jilid II, 93. Muhammad Ibn 'Ali Ibn Muhammad al-Shawkānī, Fath al-Qadìr (Kairo: Mustafa al-Bābī alHalabī, 1964), jilid I, 224, dikutip dalam Peunoh Daly, "Hukum Nikah, Talak, Rujuk, Hadanah dan Nafkah Kerabat dalam Naskah Mir'āt al-Tullāb 


\section{Pernikahan dengan Budak}

Adapun pernikahan dengan budak, pasal 28.3 UUM menjelaskan:

"Adapun jikalau ada merdehika laki-laki itu harus kahwin dengan abdi itu melainkan dengan empat syarat juga maka harus. Adapun syarat pertama (jika laki-laki itu merdehika, belum beristeri perempuan) merdehika, maka ia harus kahwin dengan 'abdi itu. (Kedua syarat) sebab karena tiada tertahan ingin hawa nafsunya, harus kahwin dengan 'abdi itu. <Ketiga syarat> sebab karena tiada ia kuasa memberi isi kahwin perempuan merdehika itu, maka itupun harus kahwin dengan 'abdi itu. Adapun syarat yang keempat, sebab karena 'abdi itu diislamkan, maka harus kahwin dengan dia. Demikianlah hukum merdehika laki-laki kahwin dengan perempuan 'abdi. Adapun jikalau tiada dengan syarat yang tersebut itu, tiadalah ia boleh kahwin dengan perempuan abdi itu. Adapun jikalau tiada seperti syarat itu, maka ada ia kuasa memberi isi kahwin perempuan merdehika itu, maka ia hendak kahwin dengan perempuan 'abdi itu, tiada sah nikahnya itu atas kaul yang sah itu. Adapun akan perempuan yang merdehika itu boleh ia duduk dengan laki-laki 'abdi, itupun jikalau ada dengan dua syarat diperolehnya. Pertama-tama, ada dengan redanya perempuan merdehika itu akan lakilaki 'abdi itu. Dan kedua disukakan oleh segala keluarganya itu, maka boleh ia kahwin dengan 'abdi itu. Jikalau tiada dengan dua syarat ini, niscaya terurailah kahwinnya mereka itu, atas kaul yang sah."117

Keabsahan pernikahan terletak pada satu syarat: kafäah (sederajat). Apakah budak mempunyai nilai yang sama dengan orang merdeka? Di dalam hukum Islam, fukaha sepakat bahwa lelaki merdeka dapat menikahi budak perempuan. ${ }^{118}$ Adapun mengenai perempuan merdeka, fukaha tidak sependapat. Menurut, ulama Shāfi ‘̄ dan Hanbālī bahwa perempuan merdeka tidak dapat menikahi budak lelaki, karena tidak sederajat. Fukaha Mālikī memandang bahwa perempuan merdeka dapat menikahi budak lelaki berkulit putih, tetapi tidak budak berkulit hitam,119 sementara menurut fukaha Hanafi melihat bahwa lelaki budak

Karya 'Abd Ra'uf Singkel," Disertasi Doktor, (Institut Agama Islam Negeri (IAIN) Jakarta, 1982), 599-600.

117Fang, Undang-Undang Melaka, 132 dan 134.

118Sābiq, Figh Sunna, jilid II, 130.

119al-Gazirīi, Kitāb al-Fiqh..., jilid IV, 54-60. 
dapat menikahi perempuan merdeka. ${ }^{120}$ Kita dapat menyimpulkan bahwa pasal 28.3 benar-benar berasal dari hukum Islam.

\section{Sumber Hukum Islam di dalam UUM}

Setelah menguji kembali hukum pernikahan di dalam UUM, kita ketahui bahwa UUM ini bukan hanya berasal dari mazhab Shāfi ${ }^{\top}$, tetapi juga mazhab fikih yang lain. Mazhab Shāfi ${ }^{\prime} \overline{1}$ jelas memberikan panduan utama pasal-pasal pernikahan, seperti pasal 25.1, 25.2, 26, 27 et 28.2. Kendati demikian, hal tersebut bukan berarti mazhab yang lain dikesampingkan. Ada beberapa pasal yang mencakup semua mazhab seperti pasal 37, 37.2, 28.1 dan 28.3. Dengan demikian, menurut analisis kami, hukum perkawinan di dalam UUM tidaklah benar-benar bersumber dari mazhab Shāfi'î, seperti yang dikira oleh Liaw Yock Fang, tetapi berasal dari semua mazhab yang ada di dalam fikih atau hukum Islam.

Liaw Yock Fang menjelaskan bahwa teks hukum perkawinan di dalam UUM berdasarkan kitab Abū Shugā' atau penjelasannya Fath al-Qarīb karya al-Qāsim al-Gazzī dan Hashiya 'Ala Fath al-Qarīb karya Ibrāhīm al-Bagūri. ${ }^{121}$ Saya menilai bahwa teks hukum perkawinan di dalam UUM, selain kitab al-Gazzi dan al-Bagūrī, juga berdasarkan kitab fikih al-Sharbīnī. Oleh karena itu, contohnya, pasal 27 sangat dekat dengan teks kitab Abū Shugā oleh al-Sharbīnī, di dalam kitabnya al-Iqnā'.122 Teks Abū Shugā' hanya menyebutkan lima alasan yang mana suami atau istri dapat membatalkan pernikahan. Ini adalah terjemahan teks Arab: “...bagi perempuan: gila, lepra, penyakit kulit, rataq dan qaran;... bagi lelaki: gila, lepra, penyakit kulit, zakar tanpa kepalanya

120 Al-Sarahsi, al-Mabsüt, jilid VI, 126 dan 131. Budak lelaki dapat menikahi perempuan merdeka jika budak lelaki itu dibebaskan atau ia mendapat izin dari tuannya atau orang tua perempuan merdeka itu atau dengan kerelaannya. Seorang budak lelaki berbohong sebagai lelaki merdeka, lalu perempuan itu tahu bahwa ia adalah seorang budak. Dalam kasus ini, perempuan itu dapat membatalkan atau melanjutkan pernikahan dengan keridaannya.

${ }^{121}$ Fang, Undang-Undang Melaka, 35.

122al-Sharbīnī, al-Iqnā' Fì Halli...,jilid II, 589-592. 
(gubb), dan mati layu (impoten)". 123 Saya tidak menemukan di manapun penjelasan atau komentar Abū Shugā atas istilah-istilah sulit tersebut. Akan tetapi, teks al-Sharbīnī lebih memberikan penjelasan panjang. Pertama, ia menjelaskan istilah rataq dan qaran. Rataq adalah pertumbuhan daging di dalam farji perempuan yang tidak normal (insidād alfarg bi al-lahm). Adapun karan adalah penambahan tulang farji yang tidak normal (insidād alfarg bi 'azm). ${ }^{124}$ Kedua, dalam kasus zakar yang mati layu seorang suami, teks al-Sharbīnī menjelaskan, saya kutipkan kalimat yang paling penting, bahwa "...Wa i₹̄à tasbutu, darab al-qādì labu sanat...”, jika impotensi benar-benar terjadi, maka hakim menentukan satu tahun. Artinya, setelah diperiksa bahwa impotensi benar-benar terjadi, dengan keputusan hakim, maka istri harus menunggu 1 tahun. Jika setelah satu tahun, impotensi masih tetap terjadi, maka istri mempunyai hak untuk membatalkan pernikahan seperti dijelaskan oleh al-Sharbīnī. ${ }^{125}$

Saya juga menjumpai pasal 28.3 sangat dekat dengan teks alSharbīnī, karena, pertama, paragraf-paragraf teks Abū Shugā sangat pendek, sementara teks al-Sharbīnī lebih panjang. Kedua, teks Abū Shugā' hanya bicara dua syarat agar seorang lelaki merdeka dapat menikahi budak perempuan, tetapi teks alSharbini menyebutkan tiga syarat sebagaimana yang terdapat di dalam pasal 28.3. Saya dapat menyatakan bahwa UUM berdasarkan, antara lain, dari teks al-Sharbīnī yang mengomentari teks Abū Shugāà .

Tampak jelas dari analisis tersebut bahwa hukum perkawinan tidaklah benar-benar berdasarkan kitab Abū Shugā', tetapi dari kitab-kitab yang mengomentari kitab al-Sharbīnī (977/1569). Berangkat dari sana, kami dapat memperkirakan bahwa teks UUM tidaklah ditulis pada saat yang bersamaan dengan teks-teks dan komentar-komentar atas kitab al-Sharbīnī, tetapi teks itu diperbaharui terus-meneurs. Rancangan dasar UUM telah dimulai sejak Sultan Muhammad Shah (1424-1444). Tetapi, UUM ditulis, diundangkan, dan disahkan pada masa Sultan Muzaffar Shah (1445-1458) pada pertengahan abad ke-15

123Ibid., jilid II, 589-590.

124Ibid., 590.

125 Ibid., 592. 
di Melaka. Teks UUM, menurut kami, berkembang sedikit demi sedikit.

\section{Hubungan antara Hukum Islam dan Hukum Adat}

Seperti telah kami ingatkan di atas bahwa agama di Melaka sebelum kedatangan Islam adalah Hindu dan Budha. Inilah alasan mengapa, menurut R.O. Winstedt, ${ }^{126}$ hukum adat sangat kuat terpengaruh oleh hukum Hindu. Hukum Hindu ini sendiri berasal dari India yang dibawa oleh para pedagang India. Untuk berbagai hukum yang ada di dalam UUM mengandung hukum adat dan atau hukum Hindu. Selanjutnya, ada juga jenis hukum yang ketiga, yaitu percampuran hukum, antara hukum adat (yang bersumber dari Hindu) dan hukum Islam. Adapun yang terkait dengan hukum Islam, saya menegaskan kembali keberadaannya di dalam UUM adalah sangat jelas. Sebagaimana telah dipaparkan di atas bahwa hukum pernikahan di dalam UUM tersebut benar-benar berasal dari hukum Islam. Tegasnya, untuk hukum pernikahan di dalam UUM bersumber dari hukum Islam, sementara untuk hukum yan lainnya bersumber dari hukum adat.

\section{Penerapan Hukum Pernikahan}

Terkait dengan pernikahan di Melaka, Ibn Majid pada 1462 menulis: "Orang-orang kafir menikah dengan perempuan muslimah, sementara lelaki muslim menikahi perempuan penyembah berhala. Anda tidak dapat mengetahui jika mereka muslim atau bukan."127 Hal yang sama juga diutarakan oleh Tomes Pirès pada 1511: "Dan negara itu menjalankan adat ini: seorang kafir menikahi perempuan muslimah dan seorang muslim menikahi perempuan non-muslimah berdasarkan caracara negeri tersebut $[\ldots]$...128

Menurut Ibn Majī̄ dan Pirès, lelaki Muslim dapat menikahi perempuan penyembah berhala dan lelaki non-muslim dapat

${ }^{126}$ R.O. Winstedt, "Old Malay Legal Digests and Malay Customary Law," Journal of the Royal Asiatic Society, no. 1 \& 2 (1945): 17-29; Hooker, Islamic Law in South..., 158.

127Thomaz, "The Malay Sultanate...,"; Reid, Southeast Asia...,

${ }^{128 P i r e ̀ s, ~ T h e ~ S u m a ~ O r i e n t a l . . ., ~ j i l i d ~ I I, ~} 268$. 
menikahi perempuan muslimah. Di dalam UUM, lelaki Muslim tidak dapat menikahi perempuan penyembah berhala (pasal 28.2). Di dalam hukum Islam, seorang non-muslim tidak pernah dapat menikahi perempuan muslimah, ${ }^{129}$ Dengan demikian, kita mengetahui bahwa, berdasarkan keterangan Ibn Majid dan Pirès, UUM dan hukum Islam tidak diterapkan di Melaka saat itu.

Soal perceraian, Ibn Majid menyaksikan bahwa orang-orang Islam tidak menerapkan dalam masalah perceraian berdasarkan apa yang telah digariskan oleh hukum Islam pada saat itu. Ibnu Majid menulis "..Mereka tidak memperlakukan perceraian seperti bagian dari satu perbuatan keagamaan."130

Seorang suami memenuhi kewajiban memberikan mahar kepada calon isterinya. Pirès memberikan kesaksian "“Dan jika pernikahan itu terjadi antara orang Islam, lelaki memberikan mahar 10 tahil atau 6 mas kepada isterinya yang menjadi miliknya."131 Masalah mahar merujuk kepada pasal 27 UUM. Kami menilai bahwa mahar, yang hukum Islam menyebutnya sebagai mahr mitsil, yang diterapkan bagi para bangsawan atau petinggi saat itu adalah 10 tabil atau 6 mas. Agar satu pernikahan sah, calon pengantin harus mendapatkan izin dari Sultan atau Bendahara(Perdana Menteri). Berdasarkan informasi dari Alburquerque, pernikahan tidak akan pernah sah tanpa izin dari raja atau Bendahara. ${ }^{132}$

Akhirnya, kita ketahui ternyata terdapat perbedaan besar antara undang-undang sebagai suatu yang ideal dan normatif dengan kenyataan masyarakat yang tidak mencerminkan isi dari UUM. Walaupun hukum Islam itu sendiri tidak diterapkan secara ketat berdasarkan informasi di atas, kesultanan sudah mencoba memperkenalkan hukum "baru" di tengah masyarakat Melaka saat itu. Akhirnya, kami harus tegaskan bahwa kontradiksi antara "realitas" dan "idealitas" terdapat di mana saja di dunia Islam sejak awal Islam dan tidak terjadi di Melaka saja.

${ }^{129}$ Lihat di atas di dalam pembahasan pernikahan dengan non-muslim.

${ }^{130}$ Thomaz, "The Malay Sultanate...," Reid, Southeast Asia...

${ }^{131}$ Pirès, The Suma Oriental..., jilid II, 267.

${ }^{132}$ Albuquerque, The Commentaries of the Great ...,87. 


\section{Penutup}

Kami dapat menyimpulkan bahwa UUM adalah kumpulan teks tertulis hukum adat (77\%) Melaka yang mencakup berbagai aspek. Selain hukum adat, terdapat juga hukum Islam, yang mengandung, antara lain, hukum pernikahan Islam, hukum perdagangan Islam, dan hukum pidana Islam. Hukum Islam terkandung di dalam sekitar $41 \%$ dari semua isi UUM yang utamanya adalah hukum pernikahan Islam. Teks UUM itu sendiri ditulis dan dikembangkan sedikit demi sedikit. Hukum pernikahan Islam mengambil sumbernya, terutama, dari kitab fikih al-Iqnā' karya al-Sharbīn̄̄ dari mazhab Shāfíī. Kendati demikian, semua isi UUM yang terkait dengan hukum Islam berasal dari semua mazhab fikih, yaitu Hanafì, Mālikī, Shāfíî, dan Hanbālī. UUM adalah contoh terbaik dari suatu undangundang kesultanan di dunia Melayu yang mengambil sumbernya dari kitab fikih bermazhab Shāfí̄i. UUM adalah bukti bahwa kitab fikih Shāfí', terutama al-Iqnä’ karya al-Sharbīnī, sangat berpengaruh di Nusantara.

\section{Daftar Pustaka}

Adil, Buyong Bin. Sejarah Melaka Dalam Zaman Kerajaan Melayu. Kuala Lumpur: Dewan Bahasa dan Pustaka, 1973.

Albuquerque, Afonso. The Commentaries of the Great Afonso Dalboquerque. Penerjemah Walter De Gray Birch, 4 jilid, jilid III. London: The Hakluyt Society, 1774.

Alves, Jorge M. dos Santos. "The Foreign Traders' Management in the Sultanates of the Straits of Malacca." dalam From The Mediterranean To The China Sea, disunting oleh Claude Guillot, Denys Lombard dan Roderick Ptak, 131-142. Wiesbaden: Harrassowitz Verlag, 1998.

al-Gazālī, Muhammad Ibn. al-Wasit Fì al-Madz̧hab. Disunting oleh Ahmad Mahmūd Ibrāhīm dan Muhammad Muhammad Tāmir, 7 jilid, Jilid VII, Kairo: Dār al-Salām, 1997.

al-Gazīrī, 'Abd Rahmān. Kitāb al-Fiqh 'Ala Madhāb al-Arba'a, 5 jilid. Beirut: Dār al-Fikr, 1987/1406. 
al-Shāfi'I, Muhammad Ibn Idrīs. al-Umm. Disunting oleh Muhammad Zuhrī al-Naggār, VII jilid, Beirut: Dār alMa'rifa, tanpa tahun.

al-Sarahsī, Shamsuddīn. al-Mabsūt, XXX jilid. Beirut: Dār alKutub al-'Ilmiyya, 1994/1414.

al-Sharbīnī, Shamsuddīn Ibn A hmad. al-Iqnā' Fì Halli Alfą̈̌i Abì Shugä'. Disunting oleh 'Ali 'Abd al-Hamīd Abū al-Hayr dan Muhammad Wahbī Sulaymān, 2 jilid, Jilid II, Damaskus: Dār al-Hayr, 1996.

Andaya, Barbara Watson dan Andaya, Leonard Y. A History of Malaysia. Honolulu: Univesity of Hawai'i, 2001.

Barbosa, Duarte. The Book of Duarte Barbosa 1512. Diterjemahkan dari teks Portugis edisi 1812 oleh Mansel Longworth Dames, jilid 2. London: The HakluytSociety, 1921.

Blagden, C.O. "Malacca," dalam Encyclopédie de l'Islam. Leiden dan Paris: E.J. Brill dan C. Klincksieck, 1936. 198-199.

Braddel, Rolland. The Study of Ancient Times in the Malay Peninsula and Straits of Malacca. Kuala Lumpur: MBRAS, 1989.

Chambert-Loir, Henry dan Salahudin, Siti Maryam R (ed.). Bo' Sangaji Kai: Catatan Kerajaan Bima. Jakarta: EFEO\&YOI, 2000.

Daly, Peunoh. "Hukum Nikah, Talak, Rujuk, Hadanah dan Nafkah Kerabat dalam Naskah Mir'āt al-Tullāb Karya 'Abd Ra'uf Singkel." Disertasi Doktor, Institut Agama Islam Negeri (IAIN) Jakarta, 1982, 599-600.

Djajadiningrat, Hoesein. Tinjauan Kritis Tentang Sejarah Banten, Jakarta: Djambatan, 1983.

Eredia, Godinho De. Description of Malacca and Meridional India and Cathay. Terjemah oleh J.V. Mills. Kuala Lumpur: MBRAS, 1997.

Fang, Liaw Yock. Undang-Undang Melaka. The Hague: M. Nijhoff, 1976.

Fatimi, S. Q. Islam Comes To Malaysia. Singapore: Malaysian Sociological Research Institute, 1963.

Ferrand, G. Malaka: Le Malayu et Malayur. Paris: Impimerie Nationale, 1918. 
Gaudemet, Jean. "Codes, Collections, Compilations Les Leçons de l'Histoire. De Grégorius A Jean Chappuis." Droits 24, no. La Codification I (1996): 3-16.

Gazzaniga, Jean-Louis. "Rédaction des Coutumes et Codification." Droits 26, no. La Codification II (1997): 71-80. Groeneveldt, W. P. "Notes on the Malay Archipelago and Malacca Compiled Form Chinese Sources." Verbandelingen $V$ an Het Bataviaasch Genootschap V an Kunsten En Wetenschappen XXXIX, no. I (1877): 1-144.

Guillot, Claude. "La perse et le Monde malais. Echanges commerciaux et intellectuels." Archipel 68 (2004): 159-192.

Gungwu, Wang. "The First Three Rulers of Malacca," Journal of the Malayan Branch Royal Asiatic Society XLI, no. I, July (1968): 11-22.

Hashim, Muhammad Yusoff. Kesultanan Melayu Melaka. Kuala Lumpur: Dewan Bahasa dan Pustaka, 1990.

--------. The Malay Sultanate of Malacca. Terjemah oleh D.J. Muzaffar Tate. Kuala Lumpur: Dewan Bahasa dan Pustaka, 1992.

Harun, Jelani. Undang-Undang Kesultanan Melayu dalam Perbandingan. Pulau Pinang: Universiti Sains Malaysia, 2008.

Hooker, M. B. Islamic Law in South South-East Asia. Singapore: Oxford University Press, 1984.

--------. "A Note on the Malayan Legal Digests." Journal of the Malayan Branch Royal Asiatic Society XLI, no. I, (July 1968): 157-170.

Ibn Manzhur, Lisan al-'Arab, édité par 'Abdullah Al-'Ayalilī, 3 jilid, Jilid II, Beirut: Dar Lisan al-'Arab, tanpa tahun.

Ibn Rušd, Abū al-Walīd Muhammad. Bidāya al-Mugtabid Wa Nihāya al-Muqtasid, 2 jilid. Beirut: Dār al-Fikr, tanpa tahun.

Jacq-Hergoualc'h, Michael. The Malay Peninsula Crossroads Of The Maritime Silk Road (100 BC - 1300 AD), penerjemah Victoria Hobson, Leiden: Brill, 2002.

Lanang, Tun Seri. Sulalat al-Salatin ya'ni Pertuturan Segala Raja-raja (Sejarah Melayu). Disunting oleh Muhammad Haji Salleh, Kuala Lumpur: Dewan Bahasa dan Pustaka, 1997.

Liji, Liang. Hubungan Empayar Melaka-Dinasti Ming Abad ke-15. Bangi: Universiti Kebangsaan Malaysia, 1996. 
Pigeaud, Theodore G. TH. Java in the 14th Century. A Study in Cultural History. The Nagara-Kertagama by Rakawi Prapanca of Majapabit, 1365 A.D., 5 jilid. The Hague: M. Nijhoff, $1960-$ 1963.

Pirés, Tomes. The Suma Oriental, An Account Of The East From The Red Sea To Japan, Written In Malacca And India In 1512-1515. Disunting oleh Armando Cortesao, 2 jilid, New Delhi: Asian educational services, 1990.

Reid, Anthony. Southeast Asia in the Age of Commerce 1450-1680, 2 jilid. New Haven and London: Yale University Press, 1988.

Reig, Daniel. Dictionnaire Arabe Français, Français Arabe. Paris:Larouse, 1983.

Sābiq, Sayyid. Fiqh Sunna, III jilid. Kairo, tanpa penerbit, 1988/1409.

Schacht, J. "Nikāh." dalam Encyclopédie de l'Islam, h. 26-29. Leiden: E.J. Brill, 1995.

Schrieke, B. Indonesian Sociological Studies. The Hague and Bandung: Van Hoeve, 1955.

Thomaz, Luis Filipe Ferreira Reis. "The Malay Sultanate of Melaka." dalam Southeast Asia in the Early Modern Era: Trade, Power, and Belief, disunting oleh Anthony Reid, 69-90, Ithaca and London: Cornell University Press, 1993.

Vlekke, B.H.M. Nusantara A History of Indonesia. The Hague and Bandung: Van Hoeve, 1943.

Wilkinson, R.J. "The Fall of Malacca." Journal of the Malayan Branch Royal Asiatic Society XIII, no. 2 (1935): 68-69.

----------. "The Malacca Sultanate." Journal of the Malayan Branch Royal Asiatic Society XIII, no. 2 (1935): 22-67.

Winstedt, R.O. dan de Jong, Joselin P.E. "The Maritime Laws of Malacca." Journal of the Malayan Branch Royal Asiatic Society XXIX, no. III (1956): 22-59.

Winstedt, R.O. "A History of Malaya." Journal of the Malayan Branch Royal Asiatic Society XIII, no. I (1935): 1-36. . "Old Malay Legal Digests and Malay Customary Law." Journal of the Royal Asiatic Society, no. 1 \& 2 (1945):17-29.

Wawancara dengan Claude Guillot pada Senin 7 Februari 2005. 